\title{
Index of severity of musculoskeletal symptoms in keyboardists
}

\author{
Índice de severidade de sintomas musculoesqueléticos em teclistas
}

\section{Índice de gravedad de síntomas musculoesqueléticos en tecladistas}

\author{
Carlene Silva Santos $\oplus^{[a]}$, Manoel Gomes de Araújo Neto $\oplus^{[a]}$, Ana Lourdes Avelar Nascimento $\circledast^{[a],}$ \\ Glícia Lorainne Moreira Silva $\mathbb{\circledR}^{[b]}$, Adriana Sousa Rêgo $\overbrace{}^{[a]}$, Maria Claudia Gonçalves $\mathbb{[ a ]}^{[]^{*}}$ \\ [a] Universidade Ceuma (Uniceuma), São Luís, MA, Brazil \\ [b] Universidade Estadual do Maranhão (Uema), São Luís, MA, Brazil
}

\section{Abstract}

Introduction: Musicians may present musculoskeletal pain, weakness, numbness, and tingling due to repetitive exercises. Objective: To evaluate the severity index of musculoskeletal symptoms (MS) in keyboard players. Method: A cross-sectional study including volunteers of both sexes, aged between 18 and 40 years, who performed professionally for at least 2 years, played the keyboard for at least 3 hours a week, and did not present previous history of trauma or rheumatic, neurological, and systemic diseases. The MS and its severity index were evaluated using the Nordic Musculoskeletal Questionnaire and the intensity was assessed on a scale of 4 . The difference between the prevalence of musculoskeletal pain according to the anatomical region was analyzed using Fisher's exact test. For all analyses, a significance level of 5\% was adopted. This research was conducted after the ethics committee approval (No. 2,627,609). Results: Thirty-nine volunteers with discomfort were evaluated. Pain in the thoracic and lumbar spine in the last 12 months was most common ( $n=27,69.24 \%$; $p<0.031)$, and in the last seven days, lumbar spine pain occurred in 12 (30.76\%; $<$ < 0.001). A severity index of 2 was the most frequent $(n=21,54 \%)$. Conclusion:

* CSS: undergrad student, e-mail: carlenesilvas@outlook.com MGAN: Master Student, e-mail: netto_guerrerodecristo@hotmail.com ALAN: MS, e-mail: analouavelar@hotmail.com GLMS: MS, e-mail: clio.hst@gmail.com ASR: PhD, e-mail: adricefs@yahoo.com.br MCG: PhD, e-mail: mcgfisio0@gmail.com 
Keyboardists present with MS mainly in the vertebral column, and the severity of the symptoms is significant, suggesting the importance of prevention and treatment of MS before their onset.

Keywords: Musculoskeletal Pain. Physical Therapy. Music.

\section{Resumo}

Introdução: Os profissionais da música podem apresentar desconforto musculoesquelético como dor, fraqueza, dormência e formigamento devido à realização de movimentos repetitivos. Objetivo: Avaliar a frequência e o índice de severidade dos sintomas musculoesqueléticos (SM) em músicos tecladistas. Método: Trabalho do tipo transversal, com inclusão de voluntários de ambos os gêneros, com idade entre 18 a 40 anos, que exercessem a atividade profissional há pelo menos 2 anos e tocassem teclado no mínimo 3 h semanais, excluídos daqueles que apresentassem história de traumas, doenças reumáticas e sistêmicas. Os SM e seu índice de severidade foram avaliados com o Nordic Musculoskeletal Questionnaire e a intensidade avaliada em uma escala de 0 a 4. A Diferença entre as porcentagens de relato de dor musculoesquelética por região anatômica foram analisadas através do teste exato de Fisher. Para todas as análises foi adotado o nível de significância de 5\%. Esta pesquisa foi aprovada pelo comitê de Ética parecer $n^{\circ}$ 2.627.609. Resultados: Foram avaliados $n=39$ voluntários, todos relataram sentir dor ou desconforto em pelo menos um local do corpo. A região corporal apontada com mais desconforto nos últimos 12 meses foram coluna torácica e lombar, ambos $n=27(69,24 \%)(p<0,031)$ e nos últimos sete dias coluna lombar $n=12(30,76 \%)(p<0,001)$ e o índice de severidade 2 foi o mais frequente $n=21$ (54\%). Conclusão: Pode-se concluir que os músicos tecladistas apresentam sintomas musculoesqueléticos principalmente na coluna vertebral e que a severidade dos sintomas é significativa, sugerindo a importância da prevenção e tratamento dos sintomas musculoesqueléticos antes do seu agravamento.

Palavras-chave: Dor musculoesquelética. Fisioterapia. Músicos.

\section{Resumen}

Introducción: Los profesionales músicos pueden presentar trastornos musculoesqueléticos, como dolor, debilidad, entumecimiento y hormigueo debido a los movimientos repetitivos. Objetivo: Evaluar la frecuencia y el índice de gravedad de los síntomas musculoesqueléticos (SM) en tecladistas. Método: Un estudio transversal que incluyó a voluntarios de ambos sexos, con edades comprendidas entre 18 y 40 años, que se desempeñaron profesionalmente durante al menos 2 años, tocaron el teclado como mínimo 3 horas a la semana y no presentaran antecedentes de trauma previo o enfermedades reumáticas y sistémicas. Los SM y su índice de gravedad se evaluaron mediante el Cuestionario musculoesquelético nórdico y la intensidad se evaluó en una escala de 0 a 4. La diferencia entre los porcentajes de prevalencia del dolor musculoesquelético según la región anatómica se analizó mediante la prueba exacta de Fisher. Para todos los análisis, se adoptó un nivel de significancia del 5\%. Esta investigación fue aprobada por el Comité de Ética no. 2.627.609. Resultados: Se evaluaron treinta y nueve voluntarios que declararon sentir dolor o incomodidad en al menos una región del cuerpo. El dolor en la columna torácica y lumbar en los últimos 12 meses fue lo más común ( $n=27$ en ambos, 69,24\%; $p<0,031$ ), y en los últimos siete días, el dolor en la columna lumbar ocurrió en 12 (30,76\%; p 0,001). El índice de severidad 2 fue el más frecuente $(n=21,54 \%)$. Conclusión: Los tecladistas presentaron SM principalmente en la columna vertebral, y la gravedad de los síntomas es significativa, lo que sugiere la importancia de la prevención y el tratamiento de los SM antes de su instalación.

Palabras clave: Dolor musculoesquelético. Fisioterapia. Músicos. 


\section{Introduction}

Musculoskeletal pain occurs due to work-related musculoskeletal disorders as a result of repetition and overuse of the musculature. Consequently, this damage results in pain in the bones, joints, muscles, cartilage, ligaments, tendons, tendon sheaths, and bursae. This type of pain is the most common worldwide and may present as acute or chronic and diffuse or focal. Its underlying pathophysiology remains unclear, but inflammation, fibrosis, and neurosensitive disorders may be involved [1].

According to a study published in The Lancet, musculoskeletal disorders rank second among the most disabling diseases in Brazil, second only to ischemic heart disease, and represent a significant number of years of life lived with disability. Musculoskeletal pain affects $33 \%$ of the adult population and accounts for $29 \%$ of work absenteeism due to illness. Thus, the pain may lead to disability or limitations of daily living. Financially, musculoskeletal pain in the Western society ranks second in cost compared to that of cardiovascular disease [2].

The presence of trigger points can also impair or perpetuate muscle pain. Trigger points are localized and irritable nodules in a tense muscular band and result in pain, changes in sensitivity, motor dysfunction, and anatomical manifestations [3]. Trigger points are found in active and latent patients with local and/or referred pain and are associated with muscle dysfunction, muscle weakness, and decreased range of motion [4]. Their prevalence in the general population is estimated to be $85 \%$ [5].

Musculoskeletal symptoms (MS) affect several classes of professionals, including approximately $93 \%$ of teachers from various areas. Music teachers may have some acute or chronic MS [6], which result in back, upper limb and lower limb pain, similar to that in musicians. Consequently, daily living activities [7], such as household chores, selfcare, and leisure, are impaired [8].

Public transport professionals, drivers, and collectors are often studied because of their vulnerability to daily tension and a diminishing quality of life [9] due to their long working hours [10], repetitive movements, and strict postures [11]. According to Abreu [12], 92\% of drivers have chronic musculoskeletal pain.
The most common way to evaluate musculoskeletal discomfort is through manual palpation [13] and questionnaires such as McGill's Pain [14] and the Nordic Musculoskeletal Questionnaire (NMQ) translated into Portuguese. The assessments measure anatomical regions and present dichotomous questions for four situations in the last 7 days and 12 months [15].

Music professionals are also affected by musculoskeletal discomfort and must maintain high mental control, which requires a strong relationship between motor control, musicality, and expressiveness. Approximately $85 \%$ of musicians present some musculoskeletal discomfort [16, 17]. These professionals have several predisposing factors for the appearance of occupational diseases [17], such as technique, length of study, and effort dedicated to their instrument, poor posture during their performance, technical difficulties during their execution, and muscle and joint diseases [18]. According to Lima and Simonelli [19], a musician uses the same amount of muscle activity as a sportsman. The consequences of these predisposing factors are great and lead to problems with daily living or even early career termination [20] because musicians tend to underestimate their problems and ignore pain and symptoms, such as compressive syndromes, focal dystonias, repetitive strain injuries, tendonitis, and tenosynovitis [21], which require treatment or rest [22].

Keyboardists can develop MS in the upper limb and cervical spine regions because they maintain the same position and perform repetitive hand movements for long periods. In addition to repetitive movement, the lack of specialized instruction may play a role because many musicians are self-taught. This study investigated the frequency and severity index of MS among keyboardists.

\section{Methods}

This study is a cross-sectional analytical study, in which the researcher observes and measures the variables of interest only once [23]. This study was conducted in São Luís do Maranhão, and 39 keyboardists were chosen by intentional sampling. We included instrumentalists of both sexes, aged 18 to 40 years, who had been working as keyboardists for at least 2 years and played at least 3 hours a week. We excluded those with a 
previous history of musculoskeletal system trauma, rheumatic diseases, and neurological and/or systemic diseases.

Sociodemographic data (age, marital status, and education), work-related data (workload and study, where they were trained) and clinical data (past illnesses and physical activity) were collected using a questionnaire prepared by the author.

The MS and their respective affected areas were evaluated using the NMQ translated and validated by Pinheiro [15], which is composed of questions about pain, tingling, or numbness that occurred in the 12 months and 7 days prior in nine body regions: neck/ cervical region, shoulders, arms, elbows, forearms, wrists/hands/fingers, dorsal region, lumbar region, and lower limbs with a yes or no dichotomous response. The questionnaire included questions regarding whether the volunteer was unable to perform his work, participate in daily life or leisure activities, and/or sought health services, such as consultations by doctors or physiotherapists, due to these symptoms in the last 12 months.

The questionnaire also assessed the level of symptom severity on a scale of 0 to 4 , where 0 represents the absence of symptoms, 1 represents symptoms in the last 12 months or the last seven days, 2 represents symptoms in the last 12 months and last seven days, 3 represents symptoms in the previous 7 days or 12 months and a withdrawal from activities, and 4 represents symptoms in the previous 12 months and 7 days and a withdrawal from activities.

The questionnaire does not have a question about the intensity of symptoms; however, a 4-point scale was used to assess the intensity of discomfort or pain in the above regions and 1 represented no symptoms, 2 represented mild symptoms, 3 indicated moderate symptoms, and 4 represented quite strong discomfort.

The data were processed using SPSS software version 18.0 (IBM, Chicago, IL, USA). Descriptive statistics were performed by calculating the frequency, mean, and standard deviation. The data did not present a normal distribution according to the Kolmogorov-Smirnov test, and the difference in the prevalence of musculoskeletal pain by anatomical region according to the general characteristics of the musicians as the categorical variables was analyzed using chi-square $\left(\chi^{2}\right)$ or
Fisher's exact tests. For the analyses, a significance level of $5 \%$ was used. This research was approved by the Human Research Ethics Committee (Approval number: 2.627.609).

\section{Results}

Questionnaires were administered to 41 keyboardists, but 2 people were excluded for reporting that they had fibromyalgia and accidental knee fracture/injury. Of these, 38 (97.44\%) were male, with a mean age of $28.38 \pm 6.26$ years, weight of $76.04 \pm 12.84 \mathrm{~kg}$, height of $1.71 \pm 0.06 \mathrm{~m}$, body mass index (BMI) of $26.03 \pm 4.29 \mathrm{~kg} / \mathrm{m} 2$, and length of employment of $8.41 \pm 2.1$ years. Most keyboardists were right-handed $(\mathrm{n}=36,92.30 \%)$, and most were single $(\mathrm{n}=30,76.92 \%)$, followed by married $(\mathrm{n}=8,20.51 \%)$ and widowed $(\mathrm{n}=1$, $2.56 \%)$. As for education, 20 (51.28\%) participants had completed high school, 15 (38.46\%) had graduated college, and $4(10.26 \%)$ did not complete high school; approximately, 14 (35.90\%) only played the keyboard.

Regarding the form of learning, 27 (69.23\%) had learned alone and 12 (30.77\%) had learned from an instructor in a music school, courses, workshops, or with a private tutor. Most keyboardists, $(n=20$, $51.28 \%$ ) reported dedicating 1-2 hours per day to study their instrument. Considering weekly performances, most participants ( $\mathrm{n}=23,59 \%)$, played for 8 to $12 \mathrm{~h}$. Thus, considering both show hours and study hours, most volunteers played for approximately 14 hours per week.

Most volunteers $(n=21,53.85)$ reported acquiring up to $100 \%$ of their monthly income from music and approximately 29 (74.36\%) felt discomfort, such as tingling, pain, and muscle tension, after playing. Regarding access to information on ways to prevent injuries, most volunteers ( $\mathrm{n}=23,58.98 \%)$ reported having access to such information and only 19 (48.72\%) performed stretching before playing their instrument. Most volunteers ( $\mathrm{n}=23,58.98 \%$ ) had musical activity as their only professional activity. Only $13(33.33 \%)$ performed any regular physical activity, and as for daily activities, 22 (56.41\%) reported performing domestic activities, 25 (64.11\%) used a computer, and 2 (5.12) did not do any activity (Table 1 ). 
Table 1 - Distribution of the sociodemographic profile variables of the sample $(n=39)$

\begin{tabular}{lcc}
\hline \multicolumn{1}{c}{ Variables } & N & \% \\
\hline Income earned through music practice & 7 & 17.95 \\
0 to $25 \%$ & 4 & 10.25 \\
25 to $50 \%$ & 7 & 17.95 \\
50 to $75 \%$ & 21 & 53.85 \\
75 to $100 \%$ & & \\
Discomfort after touching & 29 & 74.36 \\
Yes & 10 & 25.64 \\
No & & 58.98 \\
Access to information on how to prevent & 23 & 41.02 \\
Yes & 16 & 48.72 \\
No & & 51.28 \\
Stretching before music practice & 19 & 41.02 \\
Yes & 20 & 58.98 \\
No & & \\
Other professional activity & 16 & 33.33 \\
Yes & 23 & 67 \\
No & & \\
Physical activity regularly & 13 & 56.41 \\
Yes & 26 & 64.11 \\
No & & 05.12 \\
Day to day activity & 22 & \\
Domestic activity & 25 & 2 \\
Computer & & \\
None & & \\
\hline
\end{tabular}

All volunteers had MS in some region in the last 12 months, and 27 (69.24\%) had pain in the last 7 days. A significant difference was observed for lumbar spine pain in the last 7 days $(\mathrm{n}=12,30.76 \%)$ and in the last 12 months $(n=27,69.24 \%)$, thoracic pain in the last 12 months ( $\mathrm{n}=27,69.24 \%)$, and moderate intensity lumbar spine pain $(n=11,28.21 \%)$. The regions with the most complaints were the thoracic spine, lumbar spine, and neck regions ( $\mathrm{n}=19$, $48.72 \%$ ). When asked if the volunteers related MS to work activities, 24 (61.54\%) acknowledged this relationship with symptoms in the lumbar spine.
Only $2(5.12 \%)$ participants sought medical help because of the symptoms in the neck and shoulder regions, and $1(2.56 \%)$ sought care for wrist/hand, knee, and ankle/foot pain. Of these volunteers, $6(15.38 \%)$ were prohibited from performing activities, such as those related to work and leisure, due to symptoms in the wrist/hand region (Table 2). Regarding the severity level, 6 (15\%) participants had a severity index of $4,21(54 \%)$ presented a severity index of 2, and 12 (31\%) indicated a severity index of 1 . Severity indexes of 0 and 3 were not observed in any participant (Figure 1).

Table 2 - Frequencies of musculoskeletal symptoms by anatomical region in the sample of keyboard players evaluated $(n=39)$

\begin{tabular}{|c|c|c|c|c|c|c|c|c|c|c|}
\hline \multirow{3}{*}{ Variables } & \multicolumn{10}{|c|}{ Musculoskeletal Anatomical Region } \\
\hline & Neck & Shoulder & $\begin{array}{l}\text { Thoracic } \\
\text { spine }\end{array}$ & Elbow & $\begin{array}{l}\text { Fist / } \\
\text { hand }\end{array}$ & $\begin{array}{l}\text { Lumbar } \\
\text { spine }\end{array}$ & $\begin{array}{l}\text { Hip / } \\
\text { thigh }\end{array}$ & knee & $\begin{array}{c}\text { Ankle / } \\
\text { foot }\end{array}$ & \\
\hline & n (\%) & n (\%) & n (\%) & n (\%) & n (\%) & n (\%) & n (\%) & n (\%) & n (\%) & P Value \\
\hline $\begin{array}{l}\text { Pain in last } 7 \\
\text { days }\end{array}$ & 7 (17.95) & $5(12.82)$ & $\begin{array}{c}9 \\
(23.07)\end{array}$ & $3(7.70)$ & $\begin{array}{c}9 \\
(23.07)\end{array}$ & $\begin{array}{c}12 \\
(30.76)^{*}\end{array}$ & $5(12.82)$ & $3(7.70)$ & $\begin{array}{c}6 \\
(15.38)\end{array}$ & $<0.001$ \\
\hline $\begin{array}{l}\text { Pain in the last } \\
12 \text { months }\end{array}$ & $19(48.72)$ & $\begin{array}{c}17 \\
(43.59)\end{array}$ & $\begin{array}{c}27 \\
(69.24)^{*}\end{array}$ & $4(10.26)$ & $\begin{array}{c}23 \\
(58.98)\end{array}$ & $\begin{array}{c}27 \\
(69.24)^{*}\end{array}$ & $\begin{array}{c}14 \\
(35.90)\end{array}$ & $\begin{array}{c}12 \\
(30.77)\end{array}$ & $\begin{array}{c}18 \\
(46.16)\end{array}$ & 0.031 \\
\hline
\end{tabular}

(To be continued) 


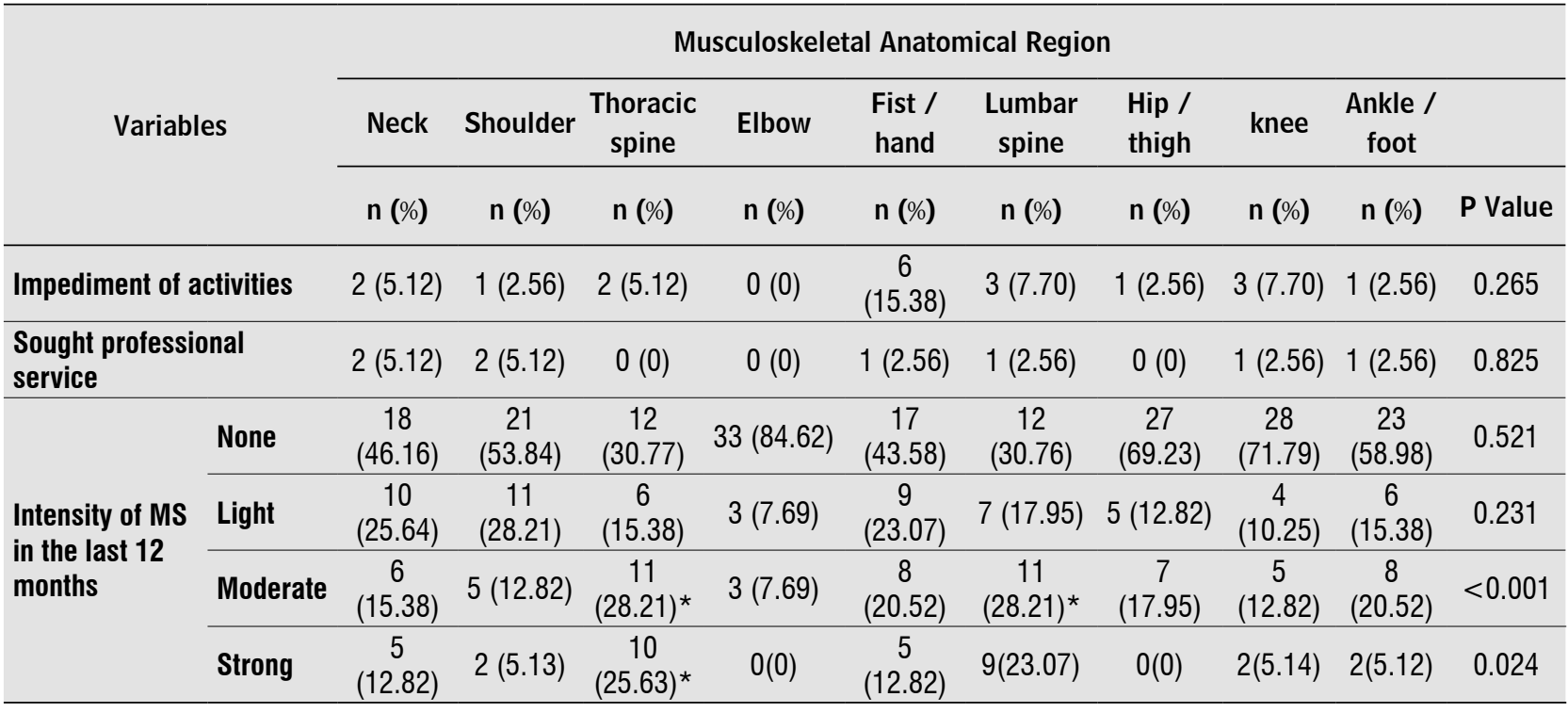

Note: * Significant difference compared to other body regions or pain intensities.

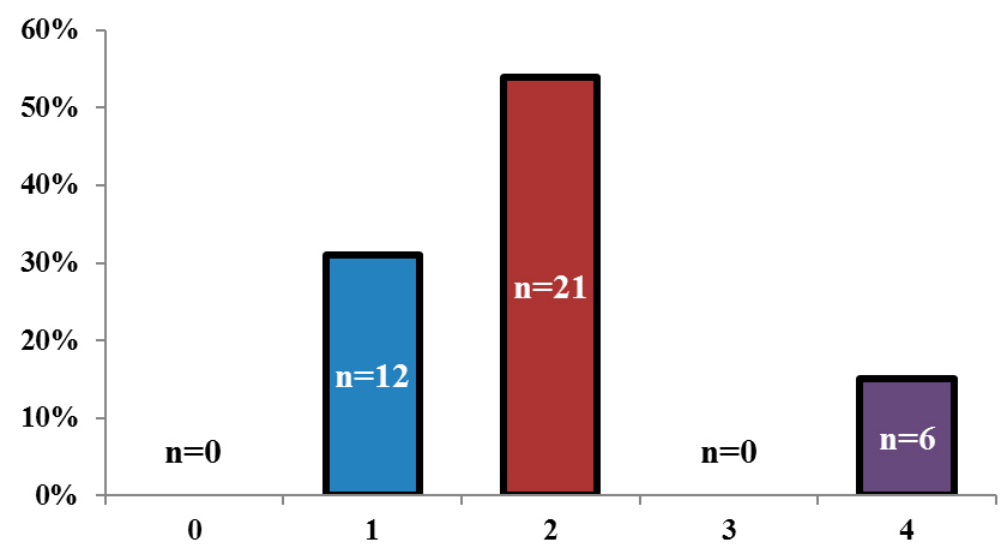

Figure 1 - Severity index provided by Nordic Musculoskeletal Questionnaire $n=39$.

\section{Discussion}

Musculoskeletal disorders can affect various classes of workers and are directly related to the force employed and repetitive movements. In this study involving keyboardists, $100 \%$ of the volunteers complained of pain or discomfort with a higher prevalence of symptoms in the spine regions. These results are similar to those of another study involving keyboardists in which Lourenço and Silva [24] observed a higher prevalence of pain in the lumbar and cervical regions. Although there was no significant difference, the shoulder, elbow, wrist, hand, hip, and ankle regions were also indicated to be common regions of pain, which was expected based on previous studies conducted on music professionals. Carvalho et al. [25] found that complaints of MS in the lower lumbar region (53.8\%), followed by the shoulder
(46.2\%), upper lumbar region (34.6\%), neck (34.6\%), and wrist and hands $(34.6 \%)$ are also frequent.

The wrist and hand region was considered the third most frequent site of complaints, which may be related to the frequent use of these structures when playing, especially when considering the sum of weekly hours of study and work related to music. In fact, symptoms of pain, tingling, and numbness in the wrist/hand region seem to be prevalent among music professionals [26]; however, the high frequency of MS observed in this study should be carefully analyzed since most volunteers also used a computer, which can be considered a confounding factor.

The high frequency of MS observed in keyboardists may be due to the posture assumed during the manipulation of the instrument in either a standing or seated position, repetitive movements, the lack of 
ergonomic orientation when learning the instrument, or the lack of preventive measures, such as stretching before playing the instrument even with prior knowledge of the ways to prevent injury. In the literature, $70 \%$ of the volunteers said they had knowledge about the forms of prevention but did not practice them $[27,28]$.

The weekly duration devoted to musical activity, even if it is lower than the weekly workload of other professionals, contributes to the emergence and aggravation of MS. A musician practices most of the time without pause and with repetitive, fast movements and asymmetrical postures that are not ergonomically oriented to his musical instrument [29], which may justify the high prevalence of MS even with a weekly workload lower than that of other professionals.

Severity level 2 was the most common severity classification in this study; that is, most volunteers had chronic and acute musculoskeletal discomfort or pain that did not impair work activities. However, the results highlight the importance of educating music professionals on the prevention and treatment of possible musculoskeletal disorders that may arise by a health professional. Our result is inconsistent with the findings of Maciel [30], who found a higher frequency of severity level 1 , which may have been due to the methodological differences between the studies since the previous author evaluated only cervical pain.

One limitation of this study was the small sample size used for convenience. The lack of studies aimed at the musician population and the use of a tool in Portuguese and validated for international use are the strengths of this work.

\section{Conclusion}

The frequency and severity of MS is high and significant among keyboardists. All volunteers in this study reported having discomfort or pain in at least one region. Given this finding, the role of the physiotherapist in the musician's health is of great importance, along with guidance on correct posture, the elimination of strained postures during music practice, and the adoption of correct ergonomics in the use of the instrument.

\section{Acknowledgments}

We thank CEUMA University for the infrastructure provided and the Maranhão Research and Technological Development Support Foundation (Fapema) for supporting the research (UNIVERSAL-01145/18).

\section{References}

1. Casser HR, Schaible HG. Musculoskeletal pain Schmerz. 2015;29(5):486-95.

2. Murray CJL, Barber RM, Foreman KJ, Ozgoren AA, Foad Abd-Allah, Semaw FA, etal. Global, regional, and national disability-adjusted life years (DALYs) for 306 diseases and injuries and healthy life expectancy (HALE) for 188 countries, 1990-2013: quantifying the epidemiological transition. Lancet. 2015;386(10009):2145-91.

3. Lavelle ED. Myofascial trigger points. Anesthesiol Clin. 2007;25(4):841-51.

4. Bron C, Dommerholt JD. Etiology of myofascial trigger points. Curr Pain Headache Rep. 2012;16(5):439-83.

5. Fleckenstein J, Zaps D, Rügger LJ, Lehmeyer L, Freiberg F, Lang PM, et al. Discrepancy between prevalence and perceived effectiveness of treatment methods in myofascial pa in syndrome: results of a crosssectional, nationwide survey. BMC Musculoskelet Disord. 2010;11:32.

6. Fernandes MH, Rocha VM, Oliveira AGRC. Fatores associados à prevalência de sintomas osteomusculares em professores. Rev Salud Publica. 2009;11(2):256-67.

7. Branco JC, Silva FG, Jansen K, Giusti PH. Prevalence of musculoskeletal symptoms in the faculty of public schools and the private school. Fisioter Mov. 2011;24(2):307-14.

8. Mango MSM, Carilho KM, Drabovski B, Joucoski E, Garcia CM, Gomes SRA. Análise dos sintomas osteomusculares de professores do ensino fundamental em Matinhos (PR). Fisioter Mov. 2012;25(4):785-94.

9. Barcza R, Duarte F. Impactos ambientais da mobilidade urbana: cinco categorias de medidas mitigadoras. Rev Bras Gest Urbana. 2012;4(1):13-9.

10. Rossi AM, Quick JC, Perrew PL. Stress e qualidade de vida no trabalho: o positivo e o negativo. São Paulo: Atlas; 2009. p. 225-30.

11. Benvegnú LA, Fassa AG, Facchini LA, Breitenbach F. Prevalência de hipertensão arterial entre motoristas 
de ônibus em Santa Maria, Rio Grande do Sul. Rev Bras Saude Ocup. 2008;33(118):32-9.

12. Abreu LA, Carvalho STRF, Soares KVBC, Nascimento ALA, Sousa PHM, Gonçalves MC. Frequency of pain musculoskeletal in transportation professionals public. São Luis-MA. Rev Investig Biomed. 2016;8:26-36.

13. Bragatto MM. Dor cervical crônica e postura em trabalhadores de escritório usuários de computador. Dissertação (Mestrado em Reabilitação e Desempenho Funcional) - Universidade de São Paulo, Ribeirão Preto; 2015.

14. Stein C, Mendl G. The German counterpart to McGill Pain Questionnaire. Pain. 1988;32(2):251-5.

15. Pinheiro FA, Trocolli BT, Carvalho VC. Validação do Questionário Nórdico de Sintomas Osteomusculares como medida de morbidade. Rev Saude Publica. 2002;36(3):307-12.

16. Silva AG, Lã FM, Afreixo V. Pain prevalence in instrumental musicians: a systematic review. Med Probl Perform Art. 2015;30(1):8-19.

17. Baadjou VA, Roussel NA, Verbunt JA, Smeets RJ, Bie RA. Systematic review: risk factors for musculoskeletal disorders in musicians. Occup Med. 2016;66:614-22.

18. Woellner SS, Marques D, Kienen ML. Distonia focal da mão em músicos: implicações para a reabilitação. Arq Catarin Med. 2013;42(3):82-8.

19. Lima J, Simonelli AP. Análise ergonômica da atividade dos músicos da Orquestra Sinfônica do Paraná: fatores de risco e cargas de trabalho. Cad Ter Ocup UFSCar. 2014;22(1):85-95.

20. Wu SJ. Occupational risk factors for musculoskeletal disorders in musicians: a systematic review. Med Probl Perform Art. 2007;22(2):43-51.

21. Silva CS, Batista JC, Cruz RI, Cruz RI, Deusdará FF, Soares DW. Músico e o superuso dos músculos esqueléticos. Coleç Pesqui Educ Fis. 2012;11(3):133-42.

22. Zuskin E, Schachter EN, Kolcić I, Polasek O, Mustajbegović J, Arumugam U. Health problems in musicians: a review. Acta Dermatovenerol Croat. 2005;13(4):247-51.

23. Badaró AFV, Guilhem D. Perfil sociodemográfico e profissional de fisioterapeutas e origem das suas concepções sobre ética. Fisioter Mov. 2011;24(3):445-54.

24. Lourenço GMG, Silva FJS. Prevalência de distúrbios posturais entre tecladistas e a atuação preventiva e corretiva da fisioterapia. Nova Fisio. 2014;18(99):66-72.

25. Carvalho ALA, Pontes BT, Massa BDL, Rodrigues SD, Almeida QTHP. Sintomas osteomusculares e desempenho ocupacional: um estudo entre músicos instrumentistas no contexto do Distrito Federal, Brasil. Rev Ter Ocup. 2016;27(2):165-71.

26. Reijani N, Benetti FA. Principais queixas osteomusculares em músicos da região do $\mathrm{ABC}$ paulista: um estudo de prevalência. ABCS Health Sci. 2016;41(1):40-5.

27. Cassapia MR, Pellenz CCO. Doenças ocupacionais e sua prevenção em estudante de música: realidade de uma instituição de ensino superior de Curitiba. Musica Hodie. 2010;10(2):91-107.

28. Fragelli TB, Gunther IA. Abordagem ecológica para avaliação dos determinantes de comportamento preventivos: inventário aplicado aos músicos. Per Musi. 2012;(25):73-84.

29. Wollner SS, Martina DM, Kienen L. Distonia focal da mão em músicos: implicações para a reabilitação. ACM Arq Catarin Med. 2013;42(3):82-8.

30. Maciel MN. Dor cervical e qualidade de vida relacionada à saúde: estudo de base populacional. [master's thesis]. Bauru, SP: Universidade do Sagrado Coração, Bauru; 2017.

Received in 01/09/2019

Recebido em 09/01/2019

Recibido em 09/01/2019

Approved in 07/22/2019

Aprovado em 22/07/2019

Aprobado em 22/07/2019 